an aqueous alkaline solution containing (DGG) $\mathrm{Na}$. $3 \mathrm{H}_{2} \mathrm{O}$ \{(DDC) Na: sodium diethyldithiocarbamate\}. When this solution is shaken with $\mathrm{CCl}_{4},(\mathrm{DDC})_{2} \mathrm{Cu}$, which is formed by the following reaction, is extracted into the $\mathrm{CGl}_{4}$ layer.

$$
\mathrm{CuS}+2(\mathrm{DDC}) \mathrm{Na} \longrightarrow(\mathrm{DDC})_{2} \mathrm{Cu}+\mathrm{Na}_{2} \mathrm{~S} \cdots \cdots(1)
$$

The indirect determination of sulfide ion is possible by measuring the absorbance of $(\mathrm{DDC})_{2} \mathrm{Cu}$ extracted in the organic layer. The detailed procedure is as follows.

Into a $50 \mathrm{~m} l$ beaker containing $2 \mathrm{ml}$ of $0.1 \mathrm{M} \mathrm{CuSO}_{4}$, $10 \mathrm{ml}$ of buffer solution $\left(\mathrm{CH}_{3} \mathrm{COOH}-\mathrm{CH}_{3} \mathrm{COONa}\right)$ of $\mathrm{pH} 4.4$ and $18 \mathrm{ml}$ of water, the sample solution of sulfide ion is dropped from a burette with stirring. The CuS precipitate formed is then allowed to stand for about 20 minutes at room temperature, filtered through a filter paper (Toyo No. 6) and washed thoroughly with the same buffer solution until the excess $\mathrm{Cu}^{2+}$ is eliminated completely. Then, into a $100 \mathrm{ml}$ separating funnel containing $40 \mathrm{ml}$ of $3 N \mathrm{NaOH}$ and $20 \mathrm{ml}$ of $\mathrm{CGl}_{4}$, the CuS precipitate is brought together with the filter paper, and about $25 \mathrm{mg}$ of (DDC) Na. $3 \mathrm{H}_{2} \mathrm{O}$ is added. After shaking for about 50 minutes, the reaction (1) is completed. The absorbance of the organic layer is measured at the wavelength of $438 \mathrm{~nm}$ against $\mathrm{CGl}_{4}$ only, because the absorbance of the reagent blank solution against $\mathrm{CCl}_{4}$ was negligible at $438 \mathrm{~nm}$.

Beer's law was well held for sulfide ion content up to $53 \mu \mathrm{g}$ and the apparent molar absorption coefficient was found to be $1.25 \times 10^{4}$. The standard deviation and the variation coefficient for $33.2 \mu \mathrm{g} \mathrm{S}^{2-}$ were $4.61 \times$ $10^{-3}$ and $0.71 \%$, respectively. Even when the precipitate was allowed to stand for about three days after filtration, the precipitate could be used for the determination of sulfide ion by the above method. The excess amount of (DDC) $\mathrm{Na} \cdot 3 \mathrm{H}_{2} \mathrm{O}$ added up to about $120 \mathrm{mg}$ gave no interference to the determination.

(Received Oct. 18, 1972)

\title{
2-ニトロソ-5-ジメチルアミノフェノールを用いる コバルトの簡易定量法
}

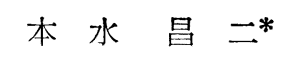

(1972 年 10 月 25 日受理)

\begin{abstract}
2-ニトロソ-5-ジメチルアミノフェノールを用いる水溶液（酸性）でのコバルトの簡易定量法につい て検討した. この定量法は, 2-ニトロソ-5-ジメチルアミノフェノールを用いる抽出-吸光光度法に比較 して, ブランクの吸光度が少し高く, 感度がわるいが $\left(530 \mathrm{~nm}\right.$ でモル吸光係数は $\left.3.1 \times 10^{4}\right)$, 操作が 簡単で，迅速な定量法である. pH 4〜8 でコバルト錯体を形成し，酸を加えたのち吸光度を測定する. これにより，試薬ブランクの吸光度は低下し，コバルト以外の錯体は分解する．検量線は試料溶液のコ バルト濃度 0 ～ $4 \times 10^{-5} M$ の範囲で直線性を示す．この定量法により，市販のニッケル塩および鉄鋼標 準試料中のコパルトの定量を行ない良好な結果を得た。
\end{abstract}

\section{1 緒言}

コバルトの定量法としては，すでに多くの報告がなさ れている.なかでもニトロソフェノール，ナフトールの 誘導体1) はコバルトに対する特異的有機試薬であり，多 くの利点を持つ. 1-ニトロソ-2-ナフトール，2-ニトロ ソ-1-ナフトール，ニトロソ R䘏などは2)3)よく用いられ ている. 以前著者は，2-ニトロソ-5-ジメチルアミノフ ェノール（以下ニトロソ-DMAP と略記）を用いるコパ

* 岡山大学理学部 : 岡山県岡山市津島
ルトの溶媒抽出一吸光光度定量法について報告した4) 8). また類似の 2-ニトロソ-5-ジェチルアミノフェノールに ついても検討し9)，海水中のコバルトの定量に応用し た ${ }^{10)}$. この二つの試薬は多くの類似点を持つ. しかし， コバルト錯体の水に対する溶解度は大きく異なり，ニト ロソ-DMAP 錯体が 18 倍よく溶ける（コバルト錯体の 溶解度 $\left.6.5 \times 10^{-5} \mathrm{~mol} / l\right)$.

今回の簡易定量法は，pH 4〜8 でコバルトとニトロ ソ-DMAP を反応させたのち, 酸を加えて酸性 $(\mathrm{pH}<1)$ とし，吸光度を測定する.酸性にすることにより，コバ 
ルト以外の金属錯体は分解され，また試薬ブランクの吸 光度は小さくなる，測定は $530 \mathrm{~nm}$ で行ない，この波長 におけるモル吸光係数は $3.1 \times 10^{4}$ である. この簡易定 量法を用いて, 鉄鋼標準試料(コバルト：0.007〜0.18\%) 中および市販の二ッケル塩中のコバルトの定量に応用し たところ良好な結果が得られたので報告する。

\section{2 試薬および装置}

\section{1 試 薬}

ニトロソ-DMAP 水溶液：既報7) と同じものを用い， $5 \times 10^{-3} M$ 溶液（塩酸 $0.01 N$ ) としてたくわえる.

コバルト標準液：塩化コバルト（石津製薬製特級）を 蒸留水に溶かし， $5 \times 10^{-3} M$ とした．この溶液の正確な コバルト濃度は EDTA で標定した ${ }^{11)}$ 。使用に際し正確 に希釈して用いた.

第二鉄イオン溶液：硫酸第二鉄アンモニウム（和光純 薬製特級）を蒸留水に溶かして用いた。

ニッケルイオン溶液: 高純度ニッケル（三津和化学薬 品製 $99.999 \%$ ) を塩酸で溶解して用いた。

銅イオン溶液 : 硫酸銅（和光純薬製特級）を用いた。 クエン酸緩衝液：クエン酸（和光純薬製特級）を水に 溶かし，水酸化ナトリウムを加えて $\mathrm{pH}$ を 5.5 付近に 調節したのち， $2 M$ になるように水で希釈して用いた。 その他の試薬は市販の特級品をそのまま用いた。

\section{$2 \cdot 2$ 装 置}

吸光度の測定は日立ーパーキンエルマー 139 型分光光 度計を用い，10 $\mathrm{mm}$ の吸収セルで吸光度を測定した。

\section{3 実験および結果}

\section{1 定量操作}

試料水溶液 $5 \mathrm{~m} l$ 它共せん付き試験管にとり, クエン 酸緩衝液 $1 \mathrm{~m} l$ を加えよく混合し 10 分間以上放置する. これにニトロソ-DMAP 溶液 $1 \mathrm{~m} l$ を加えよく混合して 10 分間以上放置する. これに塩酸 $(1+1) 3 \mathrm{ml}$ を加え 混合したのち，530 nm で $10 \mathrm{~mm}$ の吸収セルを用いて 吸光度を測定する. 同じ試料溶液 $5 \mathrm{ml}$ に塩酸 $(1+1)$ $3 \mathrm{~m} l$ を加え混合したのち, 緩衝液および試薬溶液各 $1 \mathrm{~m} l$ ずつ加えたものを試薬ブランクとして用いる.

\section{2 酸の添加および呈色の安定性}

酸として，硫酸，蓝酸および硝酸を用いたときの結果 を Fig. 1 に示す. 硝酸 $(1+1)$ の $3 \mathrm{ml}$ を添加したと きには, 約 1 時間を過ぎると急激に吸光度は減少する \{Fig. 1 の (6)\}. これは試薬が酸化分解されるためであ ろう. また硫酸 $(1+1) 3 \mathrm{ml}$ の場合にもわずかな減少 がみられる \{Fig. 1 の (1)\}。しかし，硫酸 $(1+3)$ 打 よび䘏酸 $(1+1)$ の $3 \mathrm{~m} l$ を用いた場合には，吸光度の

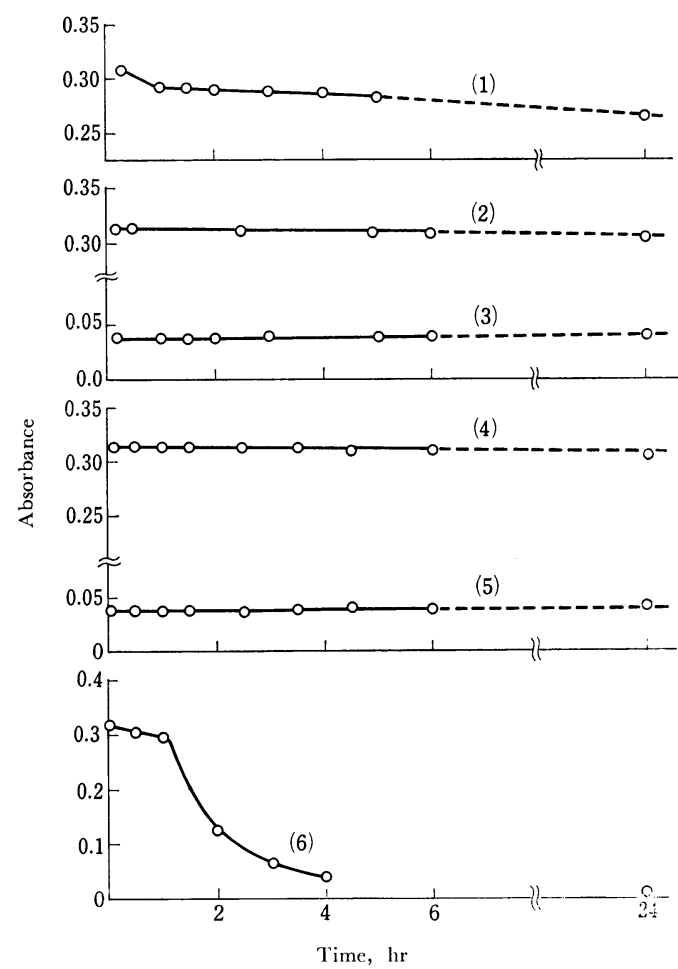

Fig. 1 Decomposition time of cobalt complex and nitroso-DMAP in acidic solution

(1) Cobalt : $1 \times 10^{-5} \mathrm{M}$, acid soln. : $\mathrm{H}_{2} \mathrm{SO}_{4}(1+1)$, ref. : reagent blank; (2) Cobalt : $1 \times 10^{-5} \mathrm{M}$, acid soln. : $\mathrm{H}_{2} \mathrm{SO}_{4}(1+3)$, ref. : reagent blank; (3) Reagent blank, acid soln. : $\mathrm{H}_{2} \mathrm{SO}_{4}(1+3)$, ref. : water; (4) Cobalt : $1 \times 10^{-5} \mathrm{M}$, acid soln. : $\mathrm{HCl}(1+$ 1), ref.: reagent blank; (5) Reagent blank, acid soln. : $\mathrm{HCl}(1+1)$, ref. : water; (6) Cobalt : $1 \times 10^{-5}$ $M$, acid soln. : $\mathrm{HNO}_{3}(1+1)$, ref. : rcagent blank; The composition of these solution are : $\left\{5 \mathrm{~m} l\right.$ of $\mathrm{H}_{2} \mathrm{O}$ or cobalt solution $\left.\left(2 \times 10^{-5} M\right)\right\}+1 \mathrm{~m} l$ of buffer solution $+1 \mathrm{~m} l$ of nitroso-DMAP solution $\left(5 \times 10^{-3} M\right)+3 \mathrm{~m} l$ of acid solution.

変化はほとんどなく，少なくとも5 時間はコバルト錯体 は安定である $\{$ Fig. 1 の (2)〜(5)\}. 鉄(III) イオンの 共存時においては，塩酸酸性のほうがブランクの吸光度 が小さいので，以後の実験では䘏酸 $(1+1)$ を用いる.

\section{3 塩酸の添加量}

壒酸 $(1+1)$ の添加量につつて調べた結果を Fig. 2 に示す. Fig. 2 より，塩酸の添加量にかかわらず，試薬 ブランクを対照としたときの吸光度は一定である. また $1.5 \mathrm{ml}$ 以上の添加量でブランクの吸光度は一定となる. このことから以下の実験では塩酸 $(1+1)$ の添加量は $3 \mathrm{~m} l$ とした. また酸の添加により, 試薬と反応してい るコバルト以外の錯体は完全に分解された. また, 試薬 


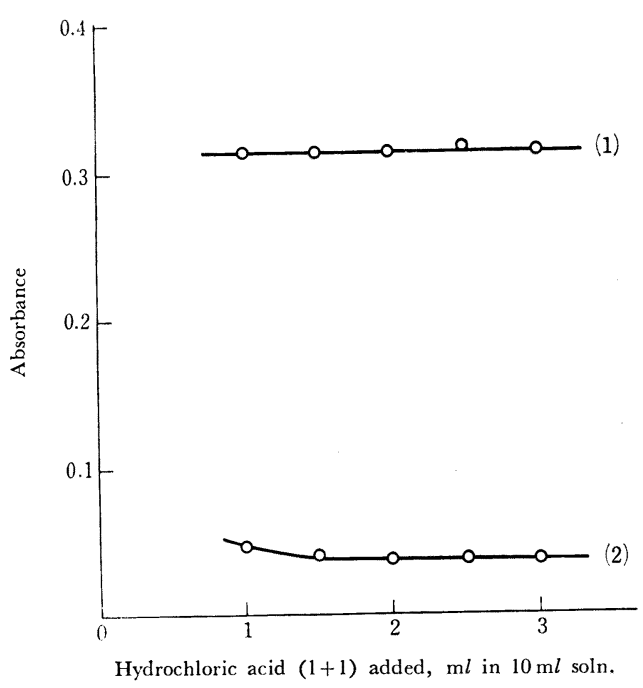

Fig. 2 Addition of hydrochloric acid $(1+1)$

(1) Cobalt : $1 \times 10^{-5} M$, ref. : reagent blank; (2) Reagent blank, ref. : water

添加前に酸を加えるとコバルトはまったく反応しないこ とがわかった。

\section{4 共存イオンの影響}

既報6)7) で調べたように，ほとえどのイオンは妨害し ないが，鉄(III)，銅およびニッケルイオンなどは妨害 する. 鉄(III), 銅(II) およびニッケルイオンについて

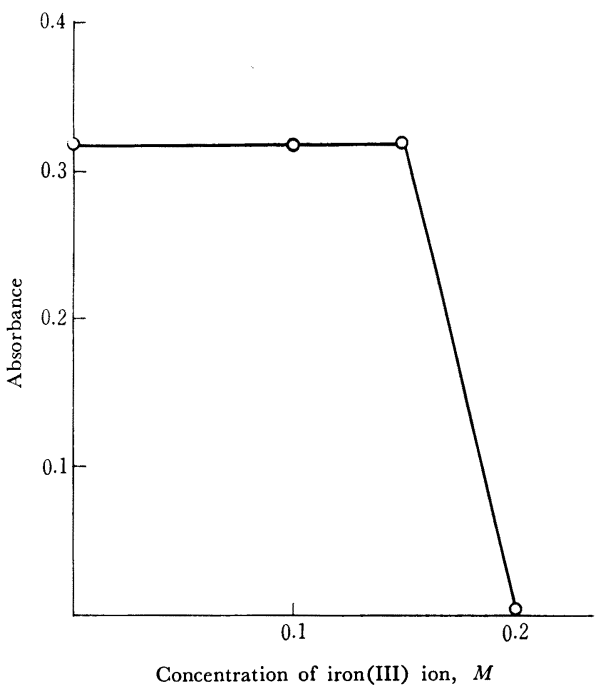

Fig. 3 Effect of iron(III) ion

Cobalt in sample solution : $2 \times 10^{-5} \mathrm{M}$; Ref. : Reagent blank
調べた結果を Fig. 3，4 に示す. 鉄は $0.15 \mathrm{~mol} / l$, 銅 は $6 \times 10^{-4} \mathrm{~mol} / l$, ニッケルは $5 \times 10^{-2} \mathrm{~mol} / l$ 存在して も妨害とならない，また，これら 3 種のイオンを含む合 成試料溶液について調べた結果を Table I に示す.

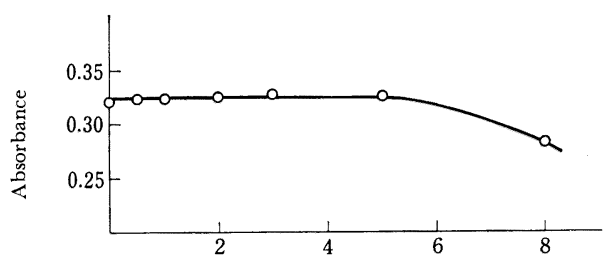

Concentration of nickel ion, $\times 10^{-2} M$

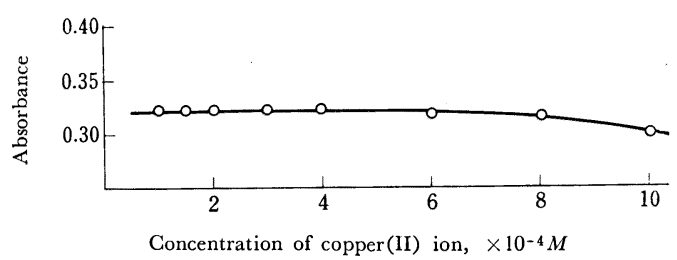

Fig. 4 Effect of nickel and copper ion

Cobalt in sample solution : $2 \times 10^{-5} M$; Ref. : Reagent blank

Table I Effect of diverse ions coexisted

\begin{tabular}{|c|c|c|c|c|c|}
\hline & Metal & $1(\mathrm{~mol} / \mathrm{l}) \dagger$ & $I_{\mathrm{M}}$ value & $I_{\mathrm{T}}$ value & Absorbance ${ }^{\prime}$ \\
\hline [1] & $\mathrm{Co}^{2+}$ & $2 \times 10^{-5}$ & & & 0.315 \\
\hline [2] & $\begin{array}{l}\mathrm{Co}^{2+} \\
\mathrm{Fe}^{3+} \\
\mathrm{Cu}^{2+} \\
\mathrm{Ni}^{2+}\end{array}$ & $\begin{array}{r}2 \times 10^{-5} \\
2.4 \times 10^{-3} \\
1 \times 10^{-4} \\
1 \times 10^{-3}\end{array}$ & $\begin{array}{l}0.16 \\
0.17 \\
0.02\end{array}$ & 0.35 & 0.320 \\
\hline [3] & $\begin{array}{l}\mathrm{Co}^{2+} \\
\mathrm{Fe}^{3+} \\
\mathrm{Cu}^{2+} \\
\mathrm{Ni}^{2+}\end{array}$ & $\begin{array}{r}2 \times 10^{-5} \\
7 \times 10^{-2} \\
2.5 \times 10^{-5} \\
1 \times 10^{-2}\end{array}$ & $\begin{array}{l}0.46 \\
0.04 \\
0.20\end{array}$ & 0.70 & 0.311 \\
\hline [4] & $\begin{array}{l}\mathrm{Co}^{2+} \\
\mathrm{Fe}^{3+} \\
\mathrm{Cu}^{2+} \\
\mathrm{Ni}^{2+}\end{array}$ & $\begin{array}{l}2 \times 10^{-5} \\
1 \times 10^{-1} \\
5 \times 10^{-5} \\
1 \times 10^{-3}\end{array}$ & $\begin{array}{l}0.66 \\
0.08 \\
0.02\end{array}$ & 0.76 & 0.326 \\
\hline [5] & $\begin{array}{l}\mathrm{Co}^{2+} \\
\mathrm{Fe}^{3+} \\
\mathrm{Cu}^{2+} \\
\mathrm{Ni}^{2+}\end{array}$ & $\begin{array}{l}2 \times 10^{-5} \\
1 \times 10^{-1} \\
5 \times 10^{-5} \\
5 \times 10^{-3}\end{array}$ & $\begin{array}{l}0.66 \\
0.08 \\
0.10\end{array}$ & 0.84 & 0.313 \\
\hline [6] & $\begin{array}{l}\mathrm{Co}^{2+} \\
\mathrm{Fe}^{3+} \\
\mathrm{Cu}^{2+} \\
\mathrm{Ni}^{2+}\end{array}$ & $\begin{array}{l}2 \times 10^{-5} \\
1 \times 10^{-1} \\
1 \times 10^{-4} \\
1 \times 10^{-2}\end{array}$ & $\begin{array}{l}0.66 \\
0.17 \\
0.20\end{array}$ & 1.03 & 0.254 \\
\hline$[7]$ & $\begin{array}{l}\mathrm{Co}^{2+} \\
\mathrm{Fe}^{3+} \\
\mathrm{Cu}^{2+} \\
\mathrm{Ni}^{2+}\end{array}$ & $\begin{array}{r}2 \times 10^{-5} \\
1.5 \times 10^{-1} \\
2 \times 10^{-4} \\
1 \times 10^{-2}\end{array}$ & $\begin{array}{l}1.00 \\
0.34 \\
0.20\end{array}$ & 1.54 & 0.225 \\
\hline
\end{tabular}

$\dagger$ Concentration in sample solution. $5 \mathrm{ml}$ of these sample solutions was used; t† Ref. : Reagent blank

妨害イオンが 2 種以上共存している場合の妨害につい ては，次のように考えるとおおよその予測ができる. 今, 妨害とならない最大のイオン濃度の逆数を妨害係数 $f$ とする. 妨害係数とそのイオンの積を $I$ とし， $I$ の和 
を $I_{\mathrm{T}}$ とする・すなわち

$$
I_{\mathrm{T}}=I_{1}+I_{2}+\cdots \cdots=f_{1} \times C_{1}+f_{2} \times C_{2}+\cdots \cdots
$$

$I_{\mathrm{T}}$ が1より小さいときには妨害はないと考光てよい． 今回の妨害金属イオンについて計算すると，

$$
\begin{aligned}
& f_{\mathrm{Fe}}=\frac{1}{0.15} \approx 6.6, f_{\mathrm{Cu}}=\frac{1}{0.0006} \approx 1.7 \times 10^{3}, \\
& f_{\mathrm{Ni}}=\frac{1}{0.05}=20
\end{aligned}
$$

となる・したがって，

$$
I_{\mathrm{T}}=6.6 \times C_{\mathrm{Fe}}+1.7 \times 10^{3} \times C_{\mathrm{Cu}}+20 \times C_{\mathrm{Ni}}
$$

\section{となる。}

Table I および Table III にIおよび $I_{\mathrm{T}}$ の值を示 す. $I_{\mathrm{T}}<0.8$ では妨害はみられない. $I_{\mathrm{T}} \approx 1$ でも $I_{\mathrm{Fe}}$ の 占める割合が大きい $\left(I_{\mathrm{Fe}} \approx 0.9\right)$ ときにはな㧍妨害はな い. しかし $I_{\mathrm{T}} \gg 1$ のときには大きく妨害する．以上の ことから，この定量法は，安全性を見込えで $I_{\mathrm{T}}<0.8$ で行なったほうがよいであろう。

\section{5 検量線}

3.1 の操作法に従って，3種の検量線を作成した．試 料溶液が鉄(III) イオンを $0.15 \mathrm{~mol} / l$ 含むもの，ニッ ケルイオンを $0.02 \mathrm{~mol} / l$ 含むものおよび鉄, ニッケル を含まないものの 3 種の検量線は, 試料溶液のコルバト 濃度 $0 \sim 4 \times 10^{-5} M$ の範囲で直線となり傾きは一致す る. 試薬ブランクを対照としたとき吸光度は $0 \sim 0.620$ であった。

\section{6 実試料中のコバルトの定量}

3.6.1 市販ニッケル塩中のコバルトの定量 市販の ニッケル塩（硫酸塩，硝酸塩および塩化物）中には特級 品で $0.02 \sim 0.07 \%, 1$ 級品で約 $0.25 \%$ のコバルトを含 えでいる6). したがって特級品では $0.1 \sim 0.2 \mathrm{~g} ， 1$ 級品 では約 $0.05 \mathrm{~g}$ はかりとり, 水に溶かし, $50 \mathrm{~m} l$ とする. Table II に 3.1 の操作法に従って市販のニッケル塩中 のコバルトを定量した結果を示す．これらの定量結果 は，吸湿性の大きい硝酸ニッケルを除いては，以前の結 果6)とよく一致している.

3.6.2 鉄鋼試料中のコバルトの定量 3.1 の操作法 に従って鉄鋼標準試料中のコバルトを定量した. コバル トの含有量が約 $0.01 \%$ のものは $0.4 \sim 0.8 \mathrm{~g}$, 約 $0.02 \%$ 以上のものは $0.4 \mathrm{~g}$ 以下をビーカーにはかりとり, 王水

\begin{tabular}{|c|c|c|c|c|c|}
\hline \multicolumn{3}{|c|}{ Sample } & \multirow{2}{*}{$\begin{array}{c}\text { Absorb- } \\
\text { ance } \dagger\end{array}$} & \multirow{2}{*}{\multicolumn{2}{|c|}{$\begin{array}{c}\text { Cobalt content } \\
(\%)\end{array}$}} \\
\hline Supplier & Grade $\dagger$ & $\begin{array}{c}\text { Taken } \\
(\mathrm{g} / 50 \mathrm{~m} l)\end{array}$ & & & \\
\hline$[\mathrm{A}] \mathrm{NiSO}_{4} \cdot 6 \mathrm{H}_{2} \mathrm{O}$ & a & 0.2037 & $\left\{\begin{array}{l}0.573 \\
0.575 \\
0.575\end{array}\right.$ & $\begin{array}{l}0.054 \\
0.054 \\
0.054\end{array}$ & $0.054+\dagger \dagger$ \\
\hline & & 0.0992 & $\left\{\begin{array}{l}0.277 \\
0.278 \\
0.278\end{array}\right.$ & $\begin{array}{l}0.053 \\
0.053 \\
0.053\end{array}$ & \\
\hline \multirow[t]{2}{*}[\mathrm{A}]{$\mathrm{Ni}\left(\mathrm{NO}_{3}\right)_{2} \cdot 6 \mathrm{H}_{2} \mathrm{O}$} & a & 0.1985 & $\left\{\begin{array}{l}0.551 \\
0.556 \\
0.561\end{array}\right.$ & $\begin{array}{l}0.053 \\
0.053 \\
0.054\end{array}$ & $0.065 t+\dagger$ \\
\hline & & 0.1026 & $\left\{\begin{array}{l}0.284 \\
0.284 \\
0.283\end{array}\right.$ & $\begin{array}{l}0.053 \\
0.053 \\
0.053\end{array}$ & \\
\hline$[\mathrm{B}] \mathrm{NiSO}_{4} \cdot 6 \mathrm{H}_{2} \mathrm{O}$ & a & 0.2021 & $\left\{\begin{array}{l}0.285 \\
0.286 \\
0.284\end{array}\right.$ & $\begin{array}{l}0.027 \\
0.027 \\
0.027\end{array}$ & $0.027+\dagger+$ \\
\hline$[\mathrm{B}] \mathrm{Ni}\left(\mathrm{NO}_{3}\right)_{2} \cdot 6 \mathrm{H}_{2} \mathrm{O}$ & a & 0.2048 & $\left\{\begin{array}{l}0.413 \\
0.413 \\
0.415\end{array}\right.$ & $\begin{array}{l}0.038 \\
0.038 \\
0.039\end{array}$ & $0.040+t \dagger$ \\
\hline$[\mathrm{C}] \mathrm{NiCl}_{2} \cdot 6 \mathrm{H}_{2} \mathrm{O}$ & e & 0.0404 & $\left\{\begin{array}{l}0.506 \\
0.505\end{array}\right.$ & $\begin{array}{l}0.24 \\
0.24\end{array}$ & $0.25 \mathrm{tt \dagger}$ \\
\hline$[\mathrm{C}] \mathrm{Ni}\left(\mathrm{NO}_{3}\right)_{2} \cdot 6 \mathrm{H}_{2} \mathrm{O}$ & e & 0.0369 & $\left\{\begin{array}{l}0.449 \\
0.449\end{array}\right.$ & $\begin{array}{l}0.23 \\
0.23\end{array}$ & $0.24+\dagger \dagger$ \\
\hline$[\mathrm{D}] \mathrm{NiSO}_{4} \cdot 7 \mathrm{H}_{2} \mathrm{O}$ & e & 0.0417 & $\left\{\begin{array}{l}0.574 \\
0.577\end{array}\right.$ & $\begin{array}{l}0.26 \\
0.26\end{array}$ & $0.27 t+\dagger$ \\
\hline
\end{tabular}
$3 \sim 6 \mathrm{~m} l$ で加熱分解する. 塩類が析出しはじめるまで蒸 発し，これに濃塩酸 $0.5 \sim 1 \mathrm{~m} l$ を加えて加熱する. 塩
Table II Determination of cobalt in nickel salts

$\dagger \mathrm{a}$ and $\mathrm{e}$ denote analytical-reagent grade and extra pure reagent, respectively; t† Ref. : Reagent blank; ††† Obtained by the solvent extraction-spectrophotometric determination in the previous

\begin{tabular}{|c|c|c|c|c|c|}
\hline & Sample & $\begin{array}{l}\text { Sample taken } \\
(\mathrm{g} / 100 \mathrm{~m} l)\end{array}$ & $I$ value & $\begin{array}{c}\text { Absorb- } \\
\text { ancet }\end{array}$ & $\begin{array}{c}\text { Cobalt } \\
\text { found }(\%)\end{array}$ \\
\hline \multirow[t]{4}{*}{ NBS } & $55 \mathrm{e}(0.007 \%)$ & 0.4833 & $I_{\mathrm{T}}-0.66$ & 0.089 & 0.0070 \\
\hline & & 0.5000 & $I_{\mathrm{T}}-0.69$ & $\left\{\begin{array}{l}0.091 \\
0.092 \\
0.092\end{array}\right.$ & $\begin{array}{l}0.0069 \\
0.0070 \\
0.0070\end{array}$ \\
\hline & & 0.6444 & $I_{\mathrm{T}}=0.88$ & $\left\{\begin{array}{l}0.119 \\
0.110\end{array}\right.$ & $\begin{array}{l}0.0070 \\
0.0065\end{array}$ \\
\hline & & 0.8055 & $\left\{\begin{array}{l}I_{\mathrm{Fe}}=0.95 \\
I_{\mathrm{Cu}}=0.15 \\
I_{\mathrm{T}}=1.10\end{array}\right.$ & $\left\{\begin{array}{l}0.142 \\
0.143\end{array}\right.$ & $\begin{array}{l}0.0067 \\
0.0068\end{array}$ \\
\hline \multirow[t]{4}{*}{ NBS } & $19 \mathrm{~g}(0.012 \%)$ & 0.4789 & $I_{\mathrm{T}}=0.69$ & 0.147 & 0.012 \\
\hline & & 0.5028 & $I_{\mathrm{T}}=0.72$ & $\left\{\begin{array}{l}0.151 \\
0.151 \\
0.151\end{array}\right.$ & $\begin{array}{l}0.011 \\
0.011 \\
0.011\end{array}$ \\
\hline & & 0.6385 & $I_{\mathrm{T}}=0.92$ & $\left\{\begin{array}{l}0.195 \\
0.195\end{array}\right.$ & $\begin{array}{l}0.012 \\
0.012\end{array}$ \\
\hline & & 0.7981 & $\left\{\begin{array}{l}I_{\mathrm{Fe}}=0.94 \\
I_{\mathrm{Cu}}=0.19 \\
I_{\mathrm{Ni}}=0.02 \\
I_{\mathrm{T}}=1.15\end{array}\right.$ & $\left\{\begin{array}{l}0.238 \\
0.237\end{array}\right.$ & $\begin{array}{l}0.011 \\
0.011\end{array}$ \\
\hline NBS & $126 \mathrm{~b}(0.032 \%)$ & 0.2022 & $I_{\mathrm{T}}=0.27$ & $\left\{\begin{array}{l}0.167 \\
0.169 \\
0.168\end{array}\right.$ & $\begin{array}{l}0.032 \\
0.032 \\
0.032\end{array}$ \\
\hline NBS & $101 \mathrm{e}(0.18 \%)$ & 0.1046 & $I_{\mathrm{T}}-0.21$ & $\left\{\begin{array}{l}0.519 \\
0.523 \\
0.521\end{array}\right.$ & $\begin{array}{l}0.19 \\
0.19 \\
0.19\end{array}$ \\
\hline
\end{tabular}
work $^{6}$.

Table III Determination of cobalt in iron and steel

$\dagger$ Ref. : Reagent blank

類が溶解後, 冷却し, 水を加えて $100 \mathrm{~m} l$ とする. 不溶 解物が存在する場合はろ紙でろ過後乃液を試料溶液とし て用いる，定量結果を Table III に示す．これらの定 量絬果は表示のコバルト量とよく一致している. 


\section{4 絬語語}

ニトロソ-DMAP を用いるコバルトの簡易定量法につ いて検討した. ニトロソ-DMAP のコバルト錯体は水に 溶け，強い酸性溶液中でも分解しない。また酸性にする ことにより，コバルト以外の金属錯体は分解し，試薬の 吸光度も大きく低下する. モル吸光係数は $530 \mathrm{~nm}$ で $3.1 \times 10^{4}$ であった. 同じ試薬を用いる抽出一吸光光度法 に比べると，モル吸光係数は約 $1 / 2$ であるが, JIS 法で 用いられているニトロソ R 塩の約 2 倍である. 今回の定 量法の大きな利点は，操作が簡単で迅速な定量法である ことである. また，この方法と抽出一吸光光度法とを組み 合わせると, 同一の試薬で低濃度から高濃度のコバルト が定量できることは，実際面からも大きな利点となる.

今回の方法により市販のニッケル塩および鉄鋼中のコ バルトがじゅうぶえ定量できることがわかった.

終わりに，本研究を行なうにあたり試料の提供ならび に有益なご助言を賜わりました新日本製鉄株式会社（製 品技術研究所）川村和郎氏に感謝します. また終始ご指 導を賜わりました岡山大学桐栄恭二教授に感謝します.

\section{交献}

1）桐栄恭二：日本化学会第 27 秋期年会講演予稿集, II, p. 264 (1972).

2) F. D. Snell, C. T. Snell : " Colorimetric Method of Analysis", 3rd Ed., p. 352 (1958), (Van Nostrand).

3) E. B. Sandell : "Colorimetric Determination of Traces of Metals", 3rd Ed., p. 409 (1959), (Interscience Publishers, Inc.).

4) 本水昌二：本誌，20，590 (1971).

5) S. Motomizu : Anal. Chim. Acta, 56, 415(1971).

6) 本水昌二：日化，92，726(1971).

7) 本水昌二 : 本誌, 20, 1507 (1971).

8) S. Motomizu : Analyst, 97, 986 (1972).

9) S. Motomizu : Anal. Chim. Acta，投稿中.

10) S. Motomizu : ibid., 印刷中.

11）上野景平：“キレート滴定法”， p. 245 (1964),
(南江堂).

$$
\text { is }
$$

Simple method of determination of cobalt with 2-nitroso-5-dimethylaminophenol. Shoji Moтоміzu (Department of Ghemistry, Faculty of Science, Okayama University, Tsushima, Okayama-shi, Okayama)

In the present paper, the simple methods of determination of cobalt in aqueous solution are reported. The cobalt complex of 2-nitroso-5-dimethylaminophenol(nitroso-DMAP) is soluble in water to $6.5 \times$ $10^{-5} M$ and its complex is not decomposed in acidic solution. Thus, after cobalt(its concentration is below $\left.4 \times 10^{-5} M\right)$ reacted quantitatively with nitroso-DMAP at $\mathrm{pH} 4 \sim 8$, the mineral acid was added to this solution and the absorbance was measured. By addition of the acid, the absorbance of reagent blank became smaller and the other metal complexes except cobalt were decomposed completely. By this method, concentration of cobalt can be determined simply and rapidly. The procedures are as follows; (1) five milliliter portions of sample solution were pipetted into a test-tube with a stopper. To this, one milliliter of citric acid buffer solution $(2 M, \mathrm{pH}=5.5)$ was added and mixed. After standing for 10 minutes, $1 \mathrm{ml}$ of nitroso-DMAP solution $\left(5 \times 10^{-3} M\right.$ in $\left.0.01 N \mathrm{HCl}\right)$ was added and mixed. After standing for 10 minutes, $3 \mathrm{ml}$ of hydrochloric acid solution $(1+1)$ were added and mixed. The absorbance of this solution was measured at $530 \mathrm{~nm}$ in a $10 \mathrm{~mm}$-path cell. (2) $5 \mathrm{ml}$ portions of the same sample solution were pipetted into another test tube. $3 \mathrm{ml}$ of hydrochloric acid solution $(1+1)$ were added and mixed, and $1 \mathrm{~m} l$ of buffer solution and $1 \mathrm{~m} l$ of reagent solution were added and mixed. The absorbance of this solution was used as the reagent blank. The calibration curve was made by the same way as mentioned above. Most of diverse ions except iorn(III), copper(II) and nickel ions do not interfere to the present method. The permissible concentrations of iron(III), copper(II) and nickel ions were examined. By using this method, cobalt in commercial nickel salts $(0.2 \sim 0.02 \%)$ and standard steel sample $(0.18 \sim 0.007 \%)$ was determined accurately, simply and rapidly. The molar absorptivity was $3.1 \times 10^{4}$ at $530 \mathrm{~nm}$.

(Received Oct. 25, 1972) 